\title{
TOKSISITAS LETAL MOLUSKISIDA NIKLOSAMIDA PADA BENIH IKAN MAS (Cyprinus carpio)
}

\author{
Yosmaniar", Eddy Supriyono"), dan Sutrisno") \\ *) Balai Riset Perikanan Budidaya Air Tawar \\ Jl. Raya Sempur No. 1, Bogor \\ E-mail: yosmaniar@yahoo.com \\ **) Departemen Budidaya Perairan-FPIK, Institut Pertanian Bogor \\ Jl. Lingkar Kampus, Kampus IPB Darmaga, Bogor 16680
}

Naskah diterima: 17 Agustus 2008; Diterima publikasi: 15 April 2009

\begin{abstract}
ABSTRAK
Penggunaan moluskisida untuk menanggulangi hama dalam budidaya tanaman padi yang semakin meningkat berpotensi mencemari lingkungan perairan, karena mengandung residu dari bahan aktifnya. Moluskisida niklosamida $\left(\mathrm{C}_{13} \mathrm{H}_{8} \mathrm{Cl}_{2} \mathrm{~N}_{2} \mathrm{O}_{4}\right)$ merupakan bahan aktif pestisida yang digunakan untuk memberantas hama keong mas atau siput murbei (Pomacea sp.) di sawah. Dengan demikian, bahan tersebut memiliki potensi untuk mencemari lahan tempat usaha budidaya ikan. Penelitian ini bertujuan untuk mengetahui potensi toksisitas akut niklosamida terhadap benih ikan mas (Cyprinus carpio) yang ditunjukkan oleh nilai Median Lethal Concentration $\left(\mathrm{LC}_{50}\right)$ 24, 48, dan 96 jam. Penelitian dilakukan di Instalasi Riset Lingkungan Perikanan Budidaya dan Toksikologi, Cibalagung-Bogor. Menggunakan ikan mas dengan bobot individu $2,47 \pm 0,13 \mathrm{~g}$. Moluskisida yang digunakan mengandung bahan aktif niklosamida $250 \mathrm{~g} / \mathrm{L}$. Wadah pengujian berupa 21 unit akuarium kaca berukuran $40 \mathrm{~cm}$ $\times 20 \mathrm{~cm} \times 20 \mathrm{~cm}$ yang dilengkapi aerasi serta saluran pemasukan dan pengeluaran. Jumlah ikan uji setiap wadah 10 ekor dengan peubah yang diukur adalah mortalitas ikan. Selama penelitian ikan tidak diberi makan. Tahapan penelitian terdiri atas penentuan nilai ambang atas-bawah, nilai lethal time dan $\mathrm{LC}_{50}-24,48,72$, dan 96 jam. Data diolah dengan analisis probit program $\mathrm{LC}_{50}$. Hasil penelitian menunjukkan bahwa nilai $\mathrm{LC}_{50}-24,48,72$, dan 96 jam terhadap benih ikan mas adalah 0,8012 (0,7140$0,8990) ; 0,5999(0,5356-0,6719) ; 0,4511(0,4067-0,5004)$; dan 0,3849 mg/L $(0,3684-0,4061)$. Hal ini menunjukkan niklosamida termasuk pestisida yang memiliki toksisitas sangat tinggi (golongan A).
\end{abstract}

KATA KUNCl: moluskisida, toksisitas letal, keong mas, ikan mas

ABSTRACT: Study on letal toxicity of molluscicide niclosamide of 250 EC on common carp (Cyprinus carpio) fry. By: Yosmaniar, Eddy Supriyono, and Sutrisno

The use of molluscicide in aquatic as well as in terresterial agro ecosystem without properly controlled may produce detrimental effects on freshwater fisheries. Molluscicide utilization for golden apple snail (Pomacea sp.) control in rice field has increased. The ingredient potencially has a possibility to pollute aquaculture water. The experiment aimed to determine potency of lethal toxicity $\left(L C_{50}\right) 24,48,72$, and 96 hours of niclosamide on common carp (Cyprinus carpio) fry. This research was conducted at Research Station for Enviroment and Toxicology, Cibalagung-Bogor by using molluscicide containing niclosamide of 250 EC. Twenty one glass aquaria of 40 $\mathrm{cm} \times 20 \mathrm{~cm} \times 20 \mathrm{~cm}$ in size filled with $10 \mathrm{~L}$ of water were used in this experiment 
equipped with water circulation system and stockted with 10 fry per aquarium. Parameter observed was the mortality of fry and water quality. The tested fish were not fed during the treatment. Preliminary research was performed by finding concentration range, lethal time dan $L C_{50}$ of 24, 48, 72, dan 96 hours. Data obtained was analyzed using $L C_{50}$ probit analysis program. Result of the experiments indicated that the lethal toxicity ( $\left(\mathrm{C}_{50}\right.$ ) of niclosamide on common carp (Cyprinus carpio) fry were as follows: $24,48,72$, and 96 hours which were 0.8012 (0.7140-0.8990), 0.5999 (0.5356-0.6719), $0.4511(0.4067-0.5004)$, and $0,3849 \mathrm{mg} / \mathrm{L}(0.3684-0.4061)$. The niclosamide is extremely toxic (classification A).

\section{KEYWORDS: molluscicide, lethal toxicity, golden apple snail, cammon carp}

\section{PENDAHULUAN}

Pengunaan pestisida dalam bidang pertanian yang semakin meningkat telah menimbulkan dampak negatif sehingga dapat menurunkan kualitas lingkungan yang diakibatkan oleh kontaminasi pestisida. Akibat lanjut dari hal tersebut adalah timbulnya masalah pencemaran pada perairan yang harus mendapat perhatian serius yaitu misalnya kematian ikan-ikan di sawah, kolam atau sungai (Mulyani, 1973). Hal ini terjadi karena pada umumnya aktivitas pertanian seperti tanaman padi di sawah terdapat pada lingkungan perairan yang juga sebagai tempat pembuangan limbah cair yang masih mengandung residu pestisida. Akibat kegiatan tersebut, maka lingkungan perairan tawar yang merupakan sumber air untuk berbagai kegiatan budidaya perikanan dapat tercemar oleh berbagai bahan aktif yang terkandung dalam formulasi pestisida.

Di Indonesia moluskisida niklosamida digunakan untuk memberantas keong mas atau siput murbei (Pomacea sp.) yang merupakan hama dalam produksi padi di Indonesia. Sedangkan di Amerika, niklosamida biasa digunakan sebagai kontrol populasi ikan lamprey laut (Petromyzon marinus) pada aliran anak sungai danau Great (Schreier et al., 2000). Keong mas merupakan hama yang dalam aktivitasnya memotong pangkal batang padi yang masih muda (Kurniawati et al., 2008). Pengendalian secara kimia yang umum dilakukan petani Indonesia yaitu dengan menggunakan pestisida jenis moluskisida dengan bahan aktif niklosamida (IRRI. 2004).).

Penggunaan niklosamida secara intensif semenjak tahun 2000-an tersebut memiliki potensi untuk mencemari perairan pada umumnya, dan media hidup usaha budidaya ikan pada khususnya. Namun demikian sampai saat ini belum ada penelitian tentang toksisistas niklosamida terhadap organisme akuatik di Indonesia, maupun keberadaan niklosamida diperairan yang mengakibatkan pencemaran akibat dari pemakaian niklosamida di sawah.

Ikan mas merupakan salah satu komoditi perikanan yang potensial tercemar oleh niklosamida. Ikan jenis ini biasanya dibudidayakan bersama padi di sawah, kolam dan karamba jaring apung (KJA) dengan sumber air berasal dari sungai yang merupakan tempat pembuangan limbah cair pertanian. Dilaporkan bahwa moluskisida sintetik maupun nabati sangat beracun terhadap ikan (Cuong, 2002 dalam Kurniawati et al. (2008). Berdasarkan beberapa hal tersebut di atas maka perlu dilakukan studi mengenai pengaruh toksik yang ditimbulkan terhadap ikan mas sebagai akibat terpapar dalam air yang tercemar niklosamida.

Penelitian ini bertujuan untuk mengetahui potensi toksistas Niklosamida pada benih ikan mas (Cyprinus carpio) dengan mengestimasi nilai Median Lethal Concentration $\left(\mathrm{LC}_{50}\right) 24$, 48, 72, dan 96 jam.

\section{BAHAN DAN METODE}

Percobaan dilakukan di Instalasi Riset Lingkungan Perikanan Budidaya dan Toksikologi Cibalagung Balai Riset Perikanan Budidaya Air Tawar Bogor. Benih ikan mas yang digunakan berasal dari Ciherang dengan bobot individu 2,47 $\pm 0,13 \mathrm{~g}$ yang sudah diadaptasikan selama 12 hari. Moluskisida Snaildown produksi PT Agricon dengan bahan aktif niklosamida $250 \mathrm{~g} / \mathrm{L}$ dengan nama kimia 2',5-dichloro-'4 nitrosalicylanilide (UPAC) dengan rumus empiris $\mathrm{C}_{13} \mathrm{H}_{8} \mathrm{Cl}_{2} \mathrm{~N}_{2} \mathrm{O}_{4}$ (Worthing, 1987) dan menggunakan aceton p.a sebagai pelarut serta $\mathrm{KMnO}_{4}(\mathrm{PK}) 20 \mathrm{mg} / \mathrm{L}$ digunakan sebagai desifektan pada wadah pengujian sebelum penelitian dilaksanakan. Wadah 
pengujian toksisitas letal berupa akuarium kaca sejumlah 21 unit ukuran $40 \mathrm{~cm} \times 20 \mathrm{~cm} \times$ $20 \mathrm{~cm}$ yang masing-masing dilengkapi aerasi dan saluran pemasukan dan pengeluaran. Jumlah ikan uji setiap wadah 10 ekor dengan volume air $10 \mathrm{~L}$. Parameter yang diukur adalah mortalitas ikan dan sifat fisika-kimia air. Penelitian terdiri dari 3 tahapan, yaitu: 1) uji penentuan nilai kisaran; 2) uji waktu letal dan 3) uji toksisitas letal selama tahapan penelitian ikan tidak diberi makan

\section{Uji Penentuan Nilai Kisaran (Range Finding Test)}

Uji Perhitungan Nilai Kisaran dilakukan untuk menentukan nilai ambang daya racun letal moluskisida terhadap ikan mas dengan cara menentukan konsentrasi ambang atas (LC $100-24$ jam) dan ambang bawah ( LC $_{0}-48$ jam) dengan konsentrasi: 0,$00 ; 0,25 ; 0,42 ; 0,87$; $1,00 \mathrm{mg} / \mathrm{L}$. Penentuan konsentrasi larutan uji ditentukan dengan mengacu pada persamaan berikut:

$\mathrm{V}_{1} \cdot \mathrm{N}_{1}=\mathrm{V}_{2} \cdot \mathrm{N}_{2}$

di mana:

$\mathrm{N}_{1}$ = Konsentrasi $(\mathrm{mg} / \mathrm{L})$ niklosamida dalam larutan stok

$\mathrm{N}_{2}=$ Konsentrasi $(\mathrm{mg} / \mathrm{L})$ niklosamida yang diinginkan dalam media air

$\mathrm{V}_{1}=$ Volume larutan stok yang akan dimbil

$\mathrm{V}_{2}=$ Volume media air penelitian yang diinginkan

\section{Uji Waktu Letal}

Pengujian ini bertujuan untuk mengetahui tingkat peluruhan konsentrasi moluskisida niklosamida dalam air berdasarkan pada kematian ikan. Prosentase penurunan kematian ikan akan dijadikan acuan untuk menentukan presentase dan interval waktu pergantian air bagi kestabilan konsentrasi perlakuan pada tahap pengujian selanjutnya. Konsentrasi moluskisida niklosamida dianggap tidak stabil apabila kematian ikan mencapai $80 \%$ yang identik dengan penurunan konsentrasi bahan kimia tersebut mencapai 7 20\% dari kondisi awal (Koesoemadinata, 2003). Pengujian dilakukan dengan mengaplikasikan tingkat konsentrasi nilai LC $_{100}-24$ jam dengan waktu pengamatan $0 ; 12 ; 24 ; 36 ; 48$ jam. Penentuan konsentrasi larutan uji ditentukan dengan mengacu pada Persamaan 1. Larutan niklosamida disebar merata pada permukan air kemudian diaduk dengan pengaduk kaca, selanjutnya dimasukkan ikan pada waktu jam ke $0 ; 12 ; 24 ; 36$ dan dihitung mortalitas ikan Selama uji stabilitas tidak dilakukan pergantian air.

\section{Uji Toksisitas Letal}

Uji toksisitas letal yaitu untuk menentukan nilai Median Lethal Concentration $\left(\mathrm{LC}_{50}\right) 96 \mathrm{jam}$ niklosamida pada benih ikan mas (Cyprinus carpio) yang besarnya berada antara nilai ambang atas dan ambang bawah yang dapat ditentukan dengan persamaan berikut:

$\log (N / n)=k \log (a / n)$

$a / n=b / a=c / b=d / c=e / d=f / e$

di mana:

$\mathrm{N}=$ Konsentrasi ambang atas

$\mathrm{n}=$ Konsentrasi ambang bawah

$\mathrm{K}=$ Jumlah konsentrasi yang diuji (6)

a, b, c, d, e, f adalah konsentrasi yang diuji dengan nilai a sebagai konsentrasi terkecil

Pengamatan mortalitas ikan yaitu pada jam ke-0; $2 ; 4 ; 8 ; 10 ; 12 ; 24 ; 36 ; 48 ; 60 ; 72$; dan 96. Pergantian air dilakukan setiap 48 jam. Pengamatan sifat fisika-kimia air selama percobaan dilakukan meliputi suhu: $\mathrm{pH}$, kadar oksigen terlarut, karbondioksida bebas, dan $\mathrm{N}-\mathrm{NH}_{3}$ yang dilakukan setiap 24 jam sekali. Data toksisitas letal dianalisis dengan analisis probit menggunakan program komputer $\mathrm{LC}_{50}$. untuk pengamatan mortalitas ikan pada jam ke- 24; 48; 72 dan 96

\section{HASIL DAN BAHASAN}

\section{Uji Penentuan Nilai Kisaran (Range Finding Test)}

Dari uji yang dilakukan diperoleh nilai konsentrasi ambang bawah ( $\mathrm{LC}_{0}-48$ jam) sebesar $0,25 \mathrm{mg} / \mathrm{L}$, yaitu konsentrasi tertinggi dari moluskisida niklosamida yang tidak mematikan ikan mas dalam waktu 48 jam dan nilai ambang atas $\left(\mathrm{L}_{100}-24\right.$ jam) sebesar 1,00 $\mathrm{mg} / \mathrm{L}$, yaitu konsentrasi terendah moluskisida niklosamida yang dapat mematikan $100 \%$ ikan mas dalam waktu 24 jam (Tabel 1).

\section{Uji Waktu Letal}

Dari data hasil pengukuran waktu letal (Tabel 2) terhadap niklosamida pada air pemeliharaan ikan mas nilai ambang atas $\left(\mathrm{L}_{100}{ }^{-}\right.$ 24 jam) sebesar 1,00 mg/L diperoleh bahwa pergantian air dilakukan setelah $48 \mathrm{jam}$, karena 
Tabel 1. Mortalitas (\%) ikan mas pada uji ambang batas konsentrasi niklosamida

Table 1. Mortality(\%) of common carp at range finding test of niclosamide concentration

\begin{tabular}{cccccccc}
\hline \multirow{2}{*}{$\begin{array}{c}\text { Konsent rasi } \\
\text { Concentration } \\
\text { (mg/L) }\end{array}$} & $\begin{array}{c}\text { Jumlah ikan (ekor) } \\
\text { Quantity of fish (ind.) }\end{array}$ & \multicolumn{5}{c}{$\begin{array}{c}\text { Wakt u pemaparan (jam) } \\
\text { Exposure time (hours) }\end{array}$} \\
\cline { 3 - 8 } & 10 & $\mathbf{0}$ & $\mathbf{6}$ & $\mathbf{1 2}$ & $\mathbf{2 4}$ & $\mathbf{3 6}$ & $\mathbf{4 8}$ \\
\hline 0.00 & 10 & 0.0 & 0.0 & 0.0 & 0.0 & 0.0 & 0.0 \\
0.25 & 10 & 0.0 & 0.0 & 0.0 & 0.0 & 0.0 & 0.0 \\
0.42 & 10 & 0.0 & 0.0 & 0.0 & 10.0 & 20.0 & 30.0 \\
0.87 & 10 & 0.0 & 40.0 & 60.0 & 60.0 & 70.0 & 80.0 \\
1.00 & & 0.0 & 100.0 & 100.0 & 100.0 & 100.0 & 100.0 \\
\hline
\end{tabular}

Tabel 2. Mortalitas (\%) ikan mas pada uji waktu letal untuk konsentrasi $1,0 \mathrm{mg} / \mathrm{L}\left(\mathrm{LC}_{100}-24 \mathrm{jam}\right)$

Table 2. Mortality (\%) of common carp at lethal time test of 1.0 $\mathrm{mg} / \mathrm{L}\left(\mathrm{LC}_{100}-24 \mathrm{jam}\right)$ niclosamide concentration

\begin{tabular}{ccc}
\hline $\begin{array}{c}\text { Periode wakt u (jam) } \\
\text { Time period (hours) }\end{array}$ & $\begin{array}{c}\text { Jumlah ikan (ekor) } \\
\text { Quantity of fish (ind.) }\end{array}$ & $\begin{array}{c}\text { Mortalitas } \\
\text { Mortality (\%) }\end{array}$ \\
\hline 0 & 10 & 0 \\
12 & 10 & 100 \\
24 & 10 & 100 \\
36 & 10 & 100 \\
48 & 10 & 80 \\
\hline
\end{tabular}

kematian ikan sebesar $80 \%$. Hal ini sesuai dengan pendapat bahwa laju penurunan tingkat konsentrasi bahan kimia tersebut mencapai 7 20\% dari konsentrasi awal (Koesoemadinata, 2003). Penurunan mortalitas ikan terjadi pada waktu ke-48 jam sebesar $20 \%$ sehingga hal ini dijadikan acuan untuk waktu pergantian konsentrasi pada air pemeliharaan, untuk lebih jelasnya dapat dilihat pada Gambar 1.

\section{Uji Toksisitas Letal}

Dari nilai ambang atas dan ambang bawah tersebut dipilih 6 konsentrasi (menggunakan persamaan 2 dan 3), yaitu: 0,$31 ; 0,38 ; 0,46$; 0,$56 ; 0,68 ; 0,82 \mathrm{mg} / \mathrm{L}$; dan kontrol (tanpa niklosamida). Pada pengamatan jam ke- 8 semua konsentrasi yang diberikan tidak ada kematian. Mortalitas ikan pada konsentrasi $0,82 \mathrm{mg} / \mathrm{L}$ pengamatan jam ke-12 sebesar $36,67 \%$ sedangkan pada konsentrasi 0,68 $\mathrm{mg} / \mathrm{L}$ sebesar $26,67 \%$. Selanjutnya pada pengamatan jam untuk konsentrasi $0,68 \mathrm{mg} / \mathrm{L}$ dan konsentrasi $0,82 \mathrm{mg} / \mathrm{L}$ kematian $100 \%$. Pada kontrol tidak terlihat gejala klinis akibat keracunan dan tidak ditemukan ikan yang mati sampai waktu pemaparan 96 jam, hal ini menunjukkan bahwa media pemeliharaan (air) dan kondisi ikan selama pengujian baik.

Niklosamida sangat toksik untuk semua spesies ikan dan bersifat persisten dilingkungan perairan (EPA, 1999). Hasil pengamatan menunjukkan bahwa gejala klinis akibat keracunan moluskisida niklosamida yang timbul setelah jam ke-8 pada konsentrasi $0,82 \mathrm{mg} / \mathrm{L}$ berupa gerakan berenang yang tidak teratur, gerakan operkulum yang tidak teratur dan kondisi ikan mulai melemah kemudian mati. Hal ini tidak berbeda jauh dengan hasil penelitian Schoettger (1970) dimana ikan berenang tidak teratur dengan menghentak, kejang serta mengeluarkan lendir, warna kulit menjadi pucat, dan pergerakan operkulum yang tidak beraturan. Gejala yang demikian menurut Connel \& Miller (1995), merupakan tanggapan yang terjadi 


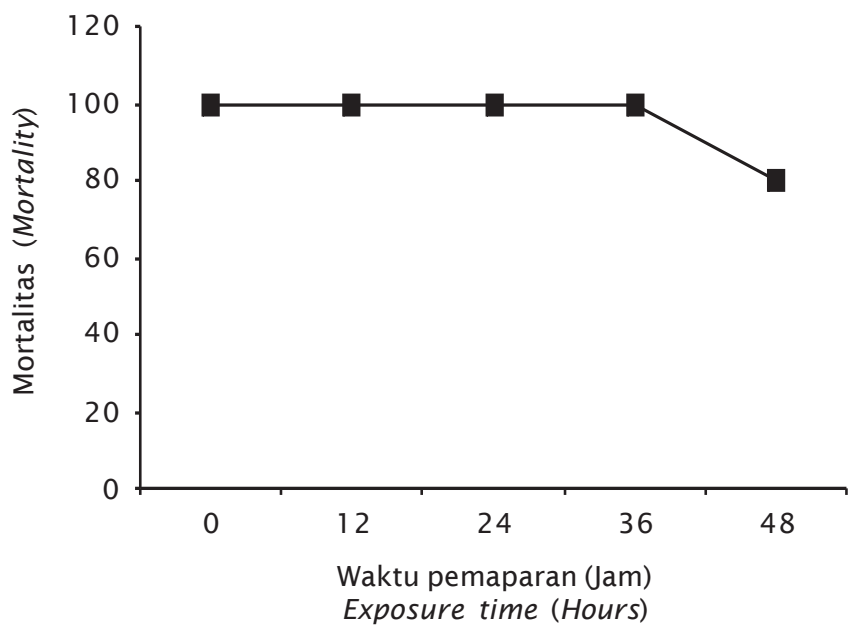

Gambar 1. Mortalitas (\%) ikan mas pada uji waktu letal untuk konsentrasi 1,0 mg/L ( LC $_{100}-24$ jam)

Figure 1. Mortality (\%) of common carp in lethal time of niclosamide( $L C_{100}-24$ jam $)$

pada saat zat-zat fisika atau kimia mengganggu proses sel atau sub sel dalam makhluk hidup sampai suatu batas yang menyebabkan kematian secara langsung.

Akibat keracunan pestisida dapat menimbulkan stres bagi ikan (Afrianto \& Liviawati, 1992). Stres adalah pengaruh beberapa perubahan lingkungan yang memperluas homeostatis atau penstabilan diluar batas normalnya (Esch \& Hazen, 1978 dalam Adams, 1990) dimana hewan tidak mampu mengatur kondisi fisiologis yang normal karena berbagai faktor merugikan yang mempengaruhi kondisi kesehatannya. Umumnya, keseluruhan respon terhadap stres berupa General adaptive syndrom (GAS). Penelitian tentang GAS umumnya terpusat pada sistem hipotalmik-pituitari-interrenal (HPI) serta pengaruhnya terhadap ikan, baik pada stres letal maupun sub letal yang disajikan pada Gambar 2.

Hasil analisis probit menunjukkan bahwa nilai $\mathrm{LC}_{50}$ pada waktu pemaparan 24, 48, 72, dan 96 jam berturut-turut 0,$8012 ; 0,5999$; 0,4511 ; dan $0,3849 \mathrm{mg} / \mathrm{L}$ (Tabel 4). Hal tersebut menunjukkan bahwa semakin lama

Tabel 3. Mortalitas (\%) ikan mas pada pengujian toksisitas letal niklosamida $250 \mathrm{~g} / \mathrm{L}$ Table 3. Mortality (\%) of common carp in lethal toxicity of nicclosamide $250 \mathrm{~g} / \mathrm{L}$

\begin{tabular}{cccccc}
\hline \multirow{2}{*}{$\begin{array}{c}\text { Konsent rasi } \\
\text { Concentration } \\
(\mathbf{m g} / \mathrm{L})\end{array}$} & $\begin{array}{c}\text { Jumlah ikan (ekor) } \\
\text { Quantity of fish (ind.) }\end{array}$ & \multicolumn{4}{c}{$\begin{array}{c}\text { Wakt u pemaparan (jam) } \\
\text { Exposure time (hours) }\end{array}$} \\
\cline { 3 - 7 } & 10 & $\mathbf{2 4}$ & $\mathbf{4 8}$ & $\mathbf{7 2}$ & $\mathbf{9 6}$ \\
\hline 0.00 & 10 & 0.00 & 0.00 & 0.00 & 0.00 \\
0.31 & 10 & 0.00 & 6.67 & 16.67 & 23.33 \\
0.38 & 10 & 6.67 & 23.33 & 40.00 & 50.00 \\
0.46 & 10 & 13.33 & 40.00 & 56.67 & 70.00 \\
0.56 & 10 & 23.33 & 50.00 & 50.00 & 83.33 \\
0.68 & 10 & 26.67 & 56.67 & 76.67 & 100.00 \\
0.82 & 10.00 & 66.67 & 86.67 & 100.00 \\
\hline
\end{tabular}




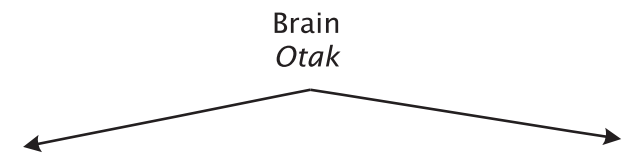

Adinohipofisis glandula pituitari

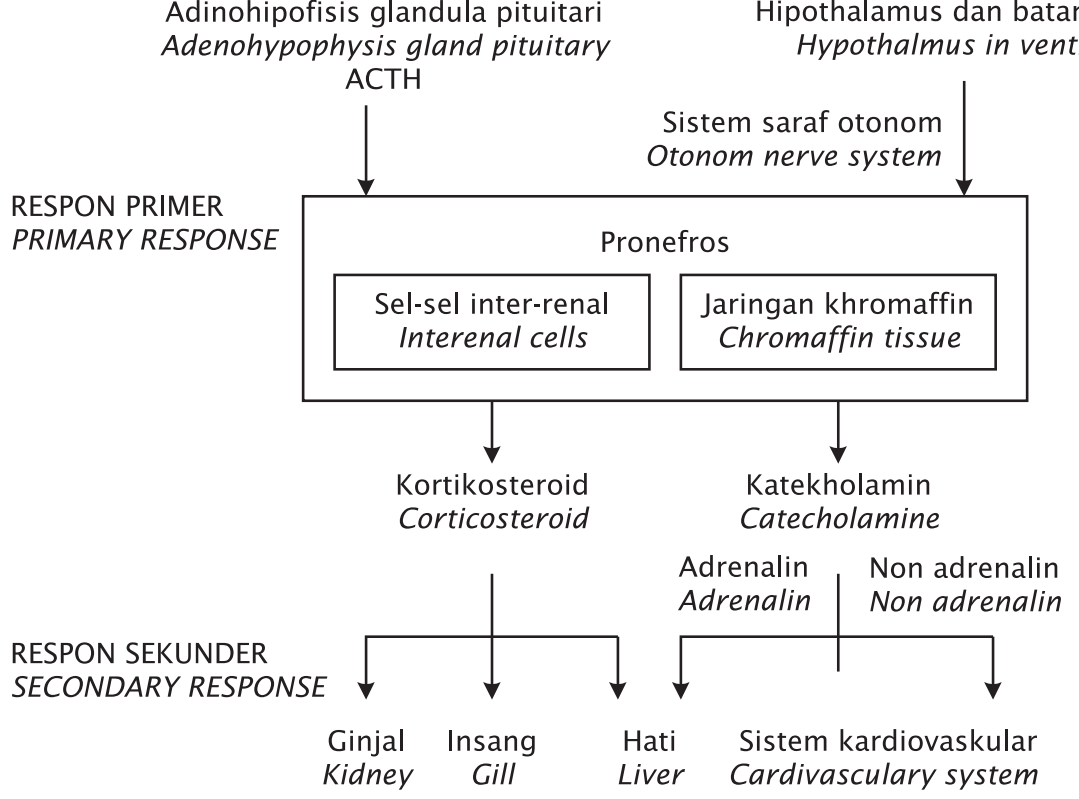

Gambar2. Rangkaian sistem hipotalmik-pituitari-interrenal (HPI) pada ikan (Sumber: Irianto, 2005)

Figure 2. Schematic of hypothalamic-pituitary-interrenal system (HPI) of fish (Source: Irianto, 2005)

waktu pemaparan akan semakin rendah nilai $\mathrm{LC}_{50}-96$ moluskisida niklosamida terhadap ikan mas (Gambar 3).

Dari hasil uji toksisitas akut diperoleh bahwa nilai LC $_{50-} 96$ jam moluskisida niklosamida terhadap ikan mas rendah yaitu sebesar $0,3849 \mathrm{mg} / \mathrm{L}(0,3684-0,4061)$.
Menurut ketentuan Komisi Pestisida (1983) dan Koesoemadinata (2003), menunjukkan toksisitas moluskisida niklosamida terhadap ikan mas diklasifikasi ke dalam golongan A, yaitu pestisida yang memiliki toksisitas sangat tinggi dengan nilai $\mathrm{LC}_{50} 96 \mathrm{jam}<1 \mathrm{mg} / \mathrm{L}$ (Tabel 5). Hal ini sesuai dengan yang dilaporkan oleh Cuong (2002) dalam Kurniawati et al. (2008)

Tabel 4. Nilai $\mathrm{LC}_{50}$ moluskisida niklosamida terhadap ikan mas pada setiap waktu pemaparan

Table 4. $L C_{50}$ molluscicide niclosamide of common carp in exposure time

\begin{tabular}{ccc}
\hline $\begin{array}{c}\text { Wakt u pemaparan (jam) } \\
\text { Exposure time (hours) }\end{array}$ & $\begin{array}{c}\text { Nilai } \mathrm{LC}_{50} \\
\text { Value of } L_{50}(\mathrm{mg} / \mathrm{L})\end{array}$ & $\begin{array}{c}\text { Persamaan garis probit } \\
\text { Equation probit line }\end{array}$ \\
\hline 24 & $0.8012(0.7140--0.8990)$ & $\mathrm{Y}=-7.1346+6.3740 \mathrm{X}$ \\
48 & $0.5999(0.5356--0.6719)$ & $\mathrm{Y}=-2.5972+4.2726 \mathrm{X}$ \\
72 & $0.4511(0.4067--0.5004)$ & $\mathrm{Y}=-2.7278+4.6712 \mathrm{X}$ \\
96 & $0.3849(0.3684--0.4061)$ & $\mathrm{Y}=-12.1973+10.8476 \mathrm{X}$ \\
\hline
\end{tabular}




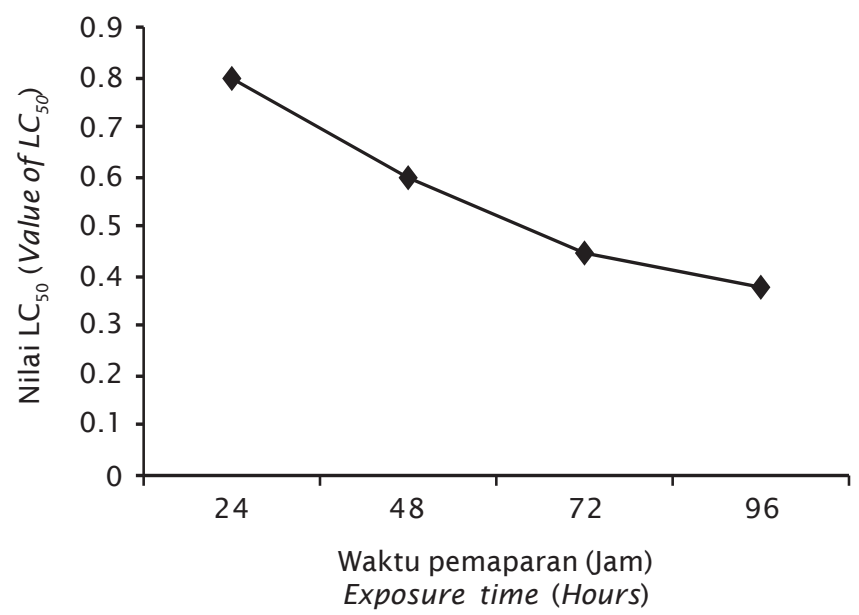

Gambar 3. Grafik Nilai $\mathrm{LC}_{50}$ moluskisida niklosamide untuk waktu pemaparan (jam)

Figure 3. The value of $L C_{50}$ molluscicide niclosamide on common carp in exposure time

bahwa moluskisida sintetik sangat beracun terhadap ikan. Selanjutnya EPA (1999) menyatakan bahwa niklosamida sangat toksik terhadap ikan seperti pada ikan rainbow trout (Oncorhyncus mykiss) dengan nilai LC $_{50}$ sebesar $0,03 \mathrm{mg} / \mathrm{L}$ dan ikan lamprey laut (Petromyzon marinus) dengan nilai $\mathrm{LC}_{50}$ yaitu $0,049 \mathrm{mg} / \mathrm{L}$.

Pentingnya nilai toksisitas letal $\left(\mathrm{LC}_{50}\right)$ karena sebagai acuan untuk toksisitas sub letal, pengaruh subletal suatu toksikan terhadap organisme dimana daya racunnya tidak menyebabkan kematian secara langsung pada organisme, tetapi menyebabkan gangguan pertumbuhan, reproduksi, kebiasaan makan. Disamping itu pengaruh yang spesifik adalah berhubungan dengan spektrum luas tanggapan fisiologis dan perilaku terhadap organisme (ikan) karena akan berpengaruh terhadap pertumbuhan (Abel, 1989).

\section{Parameter Fisika-Kimia Air}

Untuk melihat kelayakan kualitas air pemeliharaan sebagai media penelitian, dilakukan pengukuran terhadap parameter fisika-kimia air selama percobaan meliputi: suhu, pH, kadar oksigen terlarut, karbondioksida dan amoniak. Tabel 6 masih termasuk layak untuk pemeliharaan ikan.

Tabel 5. Klasifikasi pestisida berdasarkan toksisitasnya terhadap ikan

Table 5. Pesticide clasification with fish toxicity

\begin{tabular}{ccc}
\hline $\begin{array}{c}\text { Klasifikasi toksisitas } \\
\text { Toxicity clasification }\end{array}$ & $\begin{array}{c}\mathrm{LC}_{50}-96 \mathrm{jam} \\
\mathbf{5 0}\end{array}$ & $\begin{array}{c}\text { Evaluasi toksisitas } \\
\text { Toxicity evaluation }\end{array}$ \\
\hline A & $<1$ & $\begin{array}{c}\text { Sangat tinggi } \\
\text { Extremely toxic } \\
\text { Tinggi } \\
\text { H }\end{array}$ \\
C & $1-10$ & $\begin{array}{c}\text { Highly toxic } \\
\text { Sedang } \\
\text { Moderately toxic } \\
\text { Rendah } \\
\text { Lowtoxic }\end{array}$ \\
\hline
\end{tabular}

Komisi pestisida (1983) dan Koesoemadinata (2003) 
Tabel 6. Kisaran nilai mutu air toksisitas akut niklosamida

Table 6. Value range of water quality on lethal toxicity of niclosamide

\begin{tabular}{|c|c|c|c|c|c|}
\hline \multirow{2}{*}{$\begin{array}{c}\text { Konsent rasi } \\
\text { Concent rat ion } \\
(\mathrm{mg} / \mathrm{L})\end{array}$} & \multicolumn{5}{|c|}{$\begin{array}{l}\text { Parameter fisika-kimia air pemeliharaan } \\
\text { Value range of water quality on let hal toxicity of niclosamide }\end{array}$} \\
\hline & $\begin{array}{c}\text { Suhu } \\
\text { Temperat ure } \\
\left({ }^{\circ} \mathrm{C}\right)\end{array}$ & $\mathrm{pH}$ & $\begin{array}{c}\text { DO } \\
(\mathrm{mg} / \mathrm{L})\end{array}$ & $\begin{array}{c}\mathrm{CO}_{2} \\
(\mathrm{mg} / \mathrm{L})\end{array}$ & $\begin{array}{c}\text { Amoniak } \\
\text { Ammonium } \\
\text { (mg/L) }\end{array}$ \\
\hline 0.00 & 27--29 & 7.5--8.0 & 5.7--7.2 & $1.0--7.0$ & $0.02--0.033$ \\
\hline 0.31 & $27--29$ & $7.5--8.0$ & $5.8--7.2$ & $1.2--6.9$ & $0.02--0.032$ \\
\hline 0.38 & 27--29 & $7.5--8.0$ & 5.8--7.1 & $1.2--6.7$ & $0.02--0.033$ \\
\hline 0.46 & $27--29$ & $7.5--8.0$ & $5.8--7.1$ & $1.3--6.7$ & $0.02--0.033$ \\
\hline 0.56 & 27--29 & 7.6--8.0 & $5.8--7.2$ & $1.2--6.8$ & $0.02--0.032$ \\
\hline 0.68 & $27--29$ & 7.7--8.0 & $5.6--7.1$ & $1.3--6.9$ & $0.02--0.033$ \\
\hline 0.82 & $27--29$ & 7.7--8.0 & $5.7--7.2$ & $1.4--6.9$ & $0.02--0.034$ \\
\hline$N A B$ & $25-32^{1)}$ & $6-9^{3)}$ & $5-9^{3)}$ & $10^{2)}$ & $<2.20^{3)}$ \\
\hline $\begin{array}{l}\text { Keterangan: NAB = } \\
\text { 1) Boyd (1982) } \\
\text { 2) Boyd (1988) } \\
\text { 3) Chapman (1992) }\end{array}$ & Nilai Ambang Bata & & & & \\
\hline
\end{tabular}

\section{KESIMPULAN}

Dari penelitian yang sudah dilakukan dapat disimpulkan bahwa:

1. Waktu letal niklosamida di dalam air pada konsentrasi $1 \mathrm{mg} / \mathrm{L}$ adalah $48 \mathrm{jam}$.

2. Nilai $\mathrm{LC}_{50}-24,48,72$, dan 96 jam terhadap benih ikan mas adalah 0,8012; 0,5999; 0,4511 ; dan $0,3849 \mathrm{mg} / \mathrm{L}$.

3. Dari studi ini maka moluskisida niklosamida termasuk pestisida yang memiliki toksisitas sangat tinggi (golongan A) terhadap benih ikan mas.

\section{SARAN}

Masih sedikit literatur yang membahas tentang hasil penelitian niklosamida terhadap ikan. Untuk itu perlu dilakukan berbagai studi berkenaan dengan toksisitas dari niklosamida terhadap ikan.

\section{DAFTAR ACUAN}

Abel, P.D. 1989. Water Pollution Biology. Ellis Horwood Limited. Chichester, $231 \mathrm{pp}$.

Adam, S.M. 1990. Status and use of biological indicator for evaluating the effect of stress on fish. In biological indicator of stress in fish. American Fisheries Symposium 8. Bethesda, Maryland, p. 1-8.
Afrianto, E. \& Liviawaty, E. 1992. Pengendalian hama dan penyakit ikan. Penerbit Kanisius. Yogyakarta Boyd, C.E. 1982. Water quality management in aquaculture and fisheries science. Elseiver Scientific Publishing Company, Amsterdam, 312 pp.

Boyd, C.E. 1988. Water quality in warm water fish pond. Fourth Printing. Auburn University Agriculture Expriment Station. Alabama. USA, 359 pp.

Chapman, D. 1992. Water quality asessment. A guide to use of biota, sediment and water in eviromental monitoring. Chapman \& Hall. London, $585 \mathrm{pp}$.

Connel \& Miller. 1995. Kimia dan ekotoksikologi pencemaran. Penerbit Univ. Indonesia, Jakarta, p. 331-341.

Edwards, C.A. 1976. Persistent pesticides in the environment. CRC Press. Ohio, 170 pp.

EPA. 1999. Registration Eligibility Decision (RED) 3-Trifluoro-methyl 4-nitro phenol and niclosamide. United States Enviromental Protection Agency, 167 pp.

Irianto, A. 2005. Patologi ikan Teleostei. Gajah Mada Press, $253 \mathrm{pp}$.

IRRI 2004. Keong mas. Informasi ringkas Teknologi Padi. ht t p: / / w w w . knowledgebank (30 Januari2008). 
Koesoemadinata, S. 2003. Metode standar pengujian toksisitas pestisida terhadap ikan, $73 \mathrm{pp}$.

Komisi Pestisida. 1983. Pedoman umum pengujian laboratorium toksisitas letal pestisida pada ikan untuk keperluan pendaftaran. Departemen Pertanian. Jakarta, 18 pp.

Kurniawati, N., Hidayat, W. , \& Suharto, H. 2008 Daya tetas dan daya hidup keong mas pada perlakuan pestisida nabati dan insektisida. Prosiding Seminar Apresiasi Hasil Padi Menunjang P2BN. Buku 1. Balai Besar Penelitian Tanaman Padi. Badan Litbang Pertanian. Sukamandi, p. 393-402.

Mulyani. 1973. Peraturan pestisida. Laporan Direktorat Perlindungan Tanaman, Jakarta, $6 \mathrm{pp}$.
Schoettger, R.A. 1970. Aquatic toxicology of tiodan in several fish and aquatic invertebres. United States Development of the Interior Fish and Widlife Service, Bureuau of Sport Fisheries and Wildlife. Washington D.C., 31 pp.

Schreier, T.M., Dauson, V.K. , Choi, Spanjer, N.J., a\& M.A. Boogaard. 2000. Determinan of niclosamide residues in Rainbow Trout (Oncorhyncus mykiss) and Cannel Catfish (Ictalurus punctatus) fillet tissue by high performance liquid chromatography. J. Agric. Food Chem., 48: 2,212-2,215.

Worthing, C.H. 1987. The Pesticide Manual. A World Compendium. Eight Edition. Published by The British Crop Protection Council, 1,081 pp. 